\title{
PENGARUH PERDAGANGAN CENDANA TERHADAP MULTIKULTURALISME DI SOLOR PADA ABAD X-XVI
}

\author{
Oleh: \\ Wakhyuning Ngarsih ${ }^{1}$
}

\begin{abstract}
Solor as leading trades of sandalwood in Indonesia at past caused its territory to be the target of power by many parties like Majapahit, Ternate, Belanda and Portugis. Besides motivated to control Solor, they also expanded the influence in terms of politics, economics and even religion. So it is not surprising that the legacy traces were shown clearly by their influence on Solor society life. The results show that such influence ultimately leads to the emergence of a multicultural Solor society. The multiculturalism of Solor society reflected by various things such as ethnic, religious and linguistic diversity.
\end{abstract}

Keywords: Influence, Multiculturalism, Solor, Trades of Sandalwood

\section{PENDAHULUAN}

Indonesia merupakan salah satu negara kepulauan di dunia. Merujuk pada pasal 46 huruf a United Nations Convention on the Law of the Sea tahun 1982, negara kepulauan didefinisikan sebagai suatu negara yang seluruhnya terdiri atas satu atau lebih kepulauan dan dapat mencakup pulau lain. Sebagai salah satu negara kepulauan (archipelagic state) yang cukup besar, Indonesia memiliki \pm 17.480 pulau dengan luas lautnya mencapai 5,8 juta km² dengan garis pantai sepanjang \pm 95,181 $\mathrm{km}^{2}$ (Tinambunan, 2016, hlm. 17).

Dengan komposisi tersebut, jelas wilayah perairan laut yang dimiliki Indonesia lebih luas dari pada wilayah daratannya, sehingga peranan wilayah laut menjadi sangat penting bagi kehidupan bangsa dan negara. Tidak hanya itu, posisi geografis kepulauan Indonesia sangat strategis karena merupakan pusat lalu lintas maritim antar benua.

Sebagai pusat lalu lintas maritim antar benua, secara tidak langsung telah melahirkan budaya maritim yang kuat yang dimiliki oleh bangsa Indonesia. Bangsa Indonesia dengan karakteristik sosial budaya kemaritiman, bukanlah merupakan fenomena baru. Fakta sejarah menunjukan bahwa fenomena kehidupan kemaritiman, pelayaran dan perikanan beserta kelembagaan formal dan informal yang menyertainya merupakan kontinuitas dari proses perkembangan kemaritiman Indonesia masa lalu. Tidak hanya itu,

\footnotetext{
${ }^{1}$ Wakhyuning Ngarsih merupakan Peneliti di Balai Pelestarian Nilai Budaya Bali yang memiliki alamat kantor di Jl. Raya Dalung-Abianbase No. 107, Kuta Utara, Badung, Bali. Penulis dapat dihubungi melalui email: ngarsih.wakhyuning@gmail.com.
} 
budaya maritim yang berkembang di Indonesia juga telah menyatu dengan kegiatan perekonomian yang dilakukan oleh masyarakat khususnya dalam bidang perdagangan. Beberapa hasil bumi Indonesia yang menjadi komoditas perdagangan diantaranya rempah-rempah yang berasal dari Indonesia Timur dan Sumatera serta kayu cendana yang berasal dari Nusa Tenggara Timur.

Jaringan perdagangan dan pelayaran antar pulau di Indonesia telah dimulai sejak abad pertama masehi. Posisi yang strategis dan hasil sumber daya alam yang melimpah menjadikan Indonesia sebagai pusat perdagangan yang penting di jalur dagang antara Asia Timur - Asia Barat (Timur Tengah dan Semenanjung Arab). Banyak pelabuhan dagang di Indonesia yang sering dijadikan tempat singgah oleh para pedagang yang melintasi Indonesia. Salah satunya adalah pelabuhan dagang yang terdapat di Pulau Solor, Nusa Tenggara Timur.

Pulau Solor sendiri merupakan sebuah pulau yang kecil yang terletak di wilayah Flores Timur. Secara keseluruhan Pulau Solor memiliki luas $350 \mathrm{~km}$ persegi dengan batas-batas sebagai berikut: bagian utara dibatasi oleh Selat Solor, bagian timur dibatasi oleh Selat Lamakera, bagian selatan dibatasi oleh Laut Sawu dan sebelah barat dibatasi oleh Selat Lewotobi.

Menyimak kondisi geografis Pulau Solor, kawasan daratan pulau kecil ini diselingi oleh tiga wilayah pegunungan, antara lain yaitu Pegunungan Lewolein yang memanjang dengan puncak yang tidak terlalu tinggi, Pegunungan Pamakayo yang terletak memanjang searah dengan garis pantai barat Pulau Solor dengan puncaknya Ile Suban Raya, Ile Wato Emi (bekas gunung api) dan Ile Karawantung serta Pegunungan Lohayong dan Lamakera. Tanah pegunungan Lewolein, bila dibandingkan dengan kondisi pegunungan lain yang terdapat di Pulau Solor terhitung sebagai tanah pegunungan yang potensial. Selain ditumbuhi oleh berbagai jenis pepohonan yang bernilai industri, tanah pegunungan ini mengandung banyak air untuk memenuhi kebutuhan masyarakat sekitar dan masyarakat Pulau Solor pada umumnya. Tidak hanya itu, kawasan pegunungan ini juga mengandung granit. Namun sayangnya, hingga saat ini belum ada usaha untuk mengolah kandungan potensial ini demi kesejahteraan masyarakat.

Diantara ketiga wilayah pegunungan tersebut, terdapat juga dataran rendah yang sangat potensial untuk pertanian. Di dataran Wai Gawe dan Baka One (yang terletak antara pegunungan Lohayong dan Lamakera) bahkan memiliki kondisi yang sangat subur sehingga dijadikan sebagai konsentrasi daerah pertanian sekaligus menjadi gudang makanan untuk kawasan Solor Timur. Selain gunung dan dataran, kawasan pulau Solor juga memiliki beberapa sungai besar yang dapat melayani kebutuhan masyarakat. Seperti Wai Belen, Wai Daten, Wai Pukeng, Wai Duli, Wai Wulo dan lain sebagainya.

Selain sungai besar, di tanah pegunungan Lohayong dan Lamakera juga terdapat sungai-sungai kecil yang dialiri air meski dalam debet yang terbatas. Hal ini sangat bergantung pada kondisi hutan yang terdapat pada lereng kedua pegunungan tersebut. Apabila hutan dalam kondisi terawat, aliran air akan stabil dalam mengaliri sungai-sungai kecil tersebut. Namun sebaliknya, apabila hutan 
gersang dan tidak terawat, aliran air pada sungai-sungai kecil tersebut akan menjadi tidak stabil.

Kondisi geografis pulau Solor yang dikelilingi oleh beberapa pegunungan dan dialirioleh banyakaliran sungai berdampak langsung pada mata pencaharian para penduduknya. Mata pencaharian penduduk pulau Solor sendiri dapat dibedakan menjadi dua macam yaitu mata pencaharian pokok dan mata pencaharian sambilan. Mata pencaharian pokok merupakan mata pancaharian utama yang dilakukan oleh penduduk Solor, dilakukan secara berkesinambungan dan terus menerus. Sedangkan mata pencaharian sambilan dilakukan tidak secara terus menerus, hanya untuk mengisi waktu luang ketika tidak sedang melakukan aktivitas dalam kaitannya dengan mata pencaharian pokok.

Mata pencaharian pokok yang dijalani oleh mayoritas penduduk Solor adalah petani. Mereka berjuang mempertahankan hidup dengan usaha-usaha pengolahan tanah secara sederhana. Sedangkan hanya sebagian kecil yang mencoba mempertahankan hidup melalui usaha penangkapan ikan (nelayan). Kelompok penduduk yang melakukan usaha penangkapan ikan ini adalah penduduk Lohayong, Lamakera dan sekitarnya. Selain melakukan usaha penangkapan ikan untuk mempertahankan hidup, mereka juga melakukan pekerjaan sambilan dengan usaha dagang secara kecil-kecilan. Mereka berjalan keliling memanfaatkan pasar-pasar yang ada untuk menukarkan barang dagangannya dengan hasil bumi dan barang lainnya yang bermanfaat untuk hidup.

Solor meski termasuk dalam pulau yang kecil karena hanya memiliki luas 350km persegi, namun memiliki kekayaan alam yang menjadi komoditas perdagangan di nusantara yaitu kayu cendana. Jauh sebelum orang barat memasuki kawasan Nusa Tenggara Timur, kawasan ini sudah dikenal sebagai penghasil kayu cendana. Sebelum kedatangan bangsa Portugis, kayu cendana bahkan sudah menjadi bahan perdagangan di kawasan Asia.

Perdagangan kayu cendana di Nusa Tenggara Timur pada dasarnya sudah dimulai sejak abad ke sepuluh ketika para pedagang baik dari India maupun Cina mulai berkunjung ke Nusa Tenggara Timur untuk mengambil dan mengangkut kayu cendana. Dalam kitab Negara Kertagama karangan Mpu Prapanca (Lein, 1995, hlm. 18) menginformasikan bahwa kayu cendana putih yang dibawa dari Nusa Tenggara Timur pertama-tama dihantar ke Majapahit melalui Kediri sebagai bahan upeti. Sejak saat itulah Pulau Timor dan Pulau Solor khususnya mulai dikenal sebagai kawasan penghasil kayu cendana putih ini.

Selain dikenal sebagai penghasil kayu cendana, posisi Solor yang strategis juga sering menjadi alasan sebagai tempat singgah oleh kapal-kapal yang akan berlayar ke wilayah timur Indonesia. Sehingga tidak mengherankan apabila beberapa kerajaan di Nusantara dan juga bangsa asing memiliki hasrat untuk menguasai Solor seutuhnya. Seperti misalnya Kerajaan Majapahit, Kerajaan Ternate, Portugis hingga Belanda. Tidak hanya dari luar, ada pula kelompok internal yang saling berebut untuk menguasai Solor yaitu kelompok Paji dan kelompok Demong.

Perebutan kekuasaan ini pada akhirnya menimbulkan pengaruh tersendiri bagi multikulturalisme masyarakat Solor. 
Berdasarkan latar belakang uraian yang telah dipaparkan di atas, maka permasalahan dalam kajian ini akan difokuskan pada bagaimana perdagangan cendana dapat mempengaruhi multikulturalisne yang ada di Pulau Solor. Hasil dari kajian ini diharapkan dapat memberikan manfaat dalam menambah khasanah pengetahuan kesejarahan mengenai pengaruh perdagangan cendana terhadap multikulturalisme di Solor.

\section{METODE PENELITIAN}

Untuk dapat mengungkapkan tentang pengaruh perdagangan cendana terhadap multikulturalisme di Solor maka digunakan pendekatan ilmu sosial. Pendekatan ilmu sosial sangat diperlukan untuk dapat menggambarkan terjadinya perubahan sosial. Di kalangan sejarawan, telah terjadi pergeseran, bahwa sejarah tidak selalu karena masalah politik saja. Hal ini dilakukan untuk menyesuaikan diri dalam periode perubahan sosial yang sangat cepat, banyak orang yang mulai sadar akan semakin pentingnya mengetahui asal muasal dirinya dan memperbaharui ikatan dengan masa silam, terutama masa silam masyarakatnya. Jadi ilmu sejarah tidak selalu hanya kejadian politik (penceritaan tindakan dan kebijakan penguasa) saja. Tanpa kombinasi sejarah dan teori ilmu sosial maka tidak akan dapat memahami masa lau, masa kini, dan pembelajaran untuk mengambil tindakan di masa depan (Burke, 2001, hlm. 27).

Dalam relasinya dengan waktu, sejarah mengkaji dan membahas mengenai perkembangan, kesinambungan dan perubahan. Perkembangan menyangkut segala bentuk gerak perubahan masyarakat yang berturut-turut dan bertahap menuju bentuk masyarakat atau bangsa yang lebih baik dan lebih tinggi hidupnya. Kesinambungan terjadi apabila perkembangan generasi baru meneruskan apa yang telah diletakkan oleh generasi sebelumnya. Sedangkan perubahan digunakan untuk menunjukkan suatu perkembangan yang sifatnya lebih cepat dan lebih besar (Daliman, 2012, hlm. 8-9).

Adapun pendekatan ilmu sosial yang digunakan dalam kajian ini yaitu teori hegemoni dan pendekatan multikulturalisme. Teori Hegemoni memandang kebudayaan dikonstruksi dalam beragam aliran dan makna yang mencakup seperangkat ideologi, makna dan nilai budaya. Menurut Gramsci, hegemoni diartikan sebagai situasi dimana suatu "blok historis" yaitu faksi kelas berkuasa menjalankan otoritas sosial dan kepemimpinan atas kelaskelas subordinat lain melalui kombinasi antara kekuatan dan terlebih lagi dengan konsensus. Hegemoni dapat diartikan pula dominasi oleh satu kelompok terhadap kelompok lainnya, dengan atau tanpa ancaman kekerasan, sehingga ide-ide yang didiktekan oleh kelompok dominan terhadap kelompok yang didominasi diterima sebagai sesuatu yang wajar yang bersifat moral, intelektual serta budaya. Williams (1973) menyebut terdapat unsur makna yang dipandang sebagai induk dan bersifat dominan. Proses penciptaan, peneguhan dan reproduksi makna dan praktek otoritatif ini oleh Gramsci (1968) disebut dengan hegemoni budaya (Barker, 2004, hlm. 61-62).

Dalam kajian pengaruh perdagangan cendana terhadap multikulturalisme di Solor, teori hegemoni dipandang relevan untuk menganalisis bagaimana kelompok- 
kelompok yang datang dan berkuasa di Solor dapat melakukan dominasi terhadap kelompok masyarakat Solor itu sendiri sehingga dapat diterima sebagai sebuah kewajaran yang pada akhirnya juga melahirkan keanekaragaman budaya yang ada di Solor.

Pendekatanselanjutnyayangdigunakan dalam menganalisis permasalahan yang menjadi topik kajian dalam makalah ini yaitu pendekatan multikulturalisme. Multikulturalisme adalah istilah yang digunakan untuk menjelaskan pandangan seseorang tentang ragam kehidupan di dunia, ataupun kebijakan kebudayaan yang menekankan tentang penerimaan terhadap realitas keragaman, dan berbagai macam budaya (multikultural) yang ada dalam kehidupan masyarakat menyangkut nilai-nilai, sistem, budaya, kebiasaan, dan politik yang mereka anut (M. Atho Mudzhar, 2004, hlm. 174). Pendekatan mengenai multikulturalisme dalam kajian ini digunakan untuk menganalisis secara keseluruhan terkait dengan multikulturalisme yang terbentuk karena pengaruh perdangan cendana yang ada di Pulau Solor Nusa Tenggara Timur.

Metode yang digunakan dalam penelitian dan penulisan ini adalah metode sejarah, yaitu proses penelitian dan penulisan sejarah kritis yang mencakup empat langkah (Gottschalk, 1986, hlm. 34). Pertama yang dilakukan adalah heuristik yaitu mengumpulkan sebanyak mungkin sumber-sumber sejarah yang berkenaan dengan obyek penelitian. Sumber-sumber yang dimaksud baik primer maupun sekunder. Sumber tersebut tidak hanya sumber tertulis melainkan juga sumber lisan yaitu melakukan wawancara mengenai tradisi lisan yang berkembang dengan para tokoh maupun orang yang mengerti tentang peristiwa sejarah tersebut. Mengenai sumber tertulis berasal dari berbagai tulisan baik berupa dokumen/arsip, koleksi pribadi maupun berbagai buku, majalah dan surat kabar.

Langkah kedua yang ditempuh adalah dengan melakukan kritik terhadap sumber yang berhasil dikumpulkan. Kritik tersebut berupa kritik intern maupun kritik ekstern guna menetapkan sumber tersebut menjadi fakta yang valid. Dengan demikian akan dapat diputuskan bahwa sumber-sumber tersebut layak atau tidak untuk digunakan sebagai dasar penulisan.

Langkah ketiga yaitu melakukan interprestasi untuk merangkaikan berbagai fakta yang dibutuhkan dalam rangka pembuatan suatu gambaran dan juga penjelasan tentang keberadaan dan perkembangan pemerintahan di Pulau Solor. Kemudian pada langkah selanjutnya menyusun sebuah rekonstruksi sejarah mengenai pengaruh perdagangan cendana terhadap multikulturalisme di Solor, dinamika serta perubahan yang terjadi dengan merangkaikan berbagai fakta yang diperoleh dari kegiatan sebelumnya. Dengan demikian, maka pada tahap akhir dari seluruh rangkaian kegiatan ini adalah historiografi atau penulisan sejarah tentang "Pengaruh Perdagangan Cendana Terhadap Multikulturalisme Di Solor Pada Abad X-XVI”

\section{PEMBAHASAN}

\section{Kegiatan Perdagangan Cendana di Pulau Solor}

Jauh sebelum orang Barat memasuki kawasan Nusa Tenggara Timur, kawasan ini sudah dikenal sebagai penghasil kayu cendana. Sejak abad ke-X, para pedagang 
baik dari India maupun Cina mulai berkunjung ke Nusa Tenggara Timur untuk mengambil dan mengangkut kayu cendana khususnya yang berjenis cendana putih. Selama beberapa abad bahkan beberapa pedagang pengantara dari Jawa mengangkut dan menimbun kayu cendana di beberapa tempat berbeda seperti Solor, Makassar, Kediri, Sriwijaya dan Malaka.

Lein (1995, hlm. 18) menyebutkan bahwa seorang Cina dari dinasti Ming pada tahun 1436 memberitakan mengenai para pedagang Cina yang mengangkut kayu cendana, madu, lilin dan budak dari 12 pelabuhan di Timor. Setiap hari kapalkapal Cina yang dikenal dengan jung membayar pajak pelabuhan kepada para raja setempat. Pelabuhan Solor dijadikan sebagai tempat singgah yang strategis oleh para pedagang Cina pada mulanya karena mereka mengalami kesulitan di Pulau Timor dalam usaha penimbunan kayu cendana.

Oleh pedagang Cina, selain dipandang strategis Solor juga dipandang sebagai pelabuhan yang aman untuk singgah. Lohayong kemudian dipilih oleh para pedagang Cina untuk tempat tinggal sementara. Di tempat inilah kapal-kapal Cina berlabuh menantikan musim yang baik untuk meneruskan pelayaran ke Cina.

Secara garis besar, sesungguhnya ada tiga faktor yang mendorong para pedagang Cina selalu singgah di Pulau Solor. Diantaranya yaitu:

1. Pulau Solor merupakan tempat istirahat yang baik dalam pelayaran yang meletihkan menyebrangi Laut Flores dan Laut Sawu. Kondisi perairan setelah memasuki selat Lewotobi, selat Solor, selat Larantuka dan selat Adonara umumnya tenang dan menyejukan. Pelabuhan Menanga yang terletak di Desa Lohayong, Solor Timur termasuk pelabuhan alam yang aman, terlindung dari hembusan angina dan arus laut yang kencang.

2. Kondisi pulau Timor yang sering diwarnai oleh kerusuhan mendorong para pedagang memindahkan kayu cendana ke pulau Solor. Kehadiran kayu cendana di Solor menyebabkan Solor menjadi harum dan wangi. Kenyataan ini juga mendorong para pedagang menjadikan Solor sebagai tempat persinggahan.

3. Pulau Solor juga diakui sebagai tempat yang strategis untuk memantau para musuh sebelum melanjutkan perjalanan ke Nusa Nipa.

Setelah Cina, kemudian terdapat beberapa kelompok yang menjadikan Solor sebagai tempat singgah. Salah satunya adalah Majapahit. Selain kayu cendana sebagai primadona perdagangan zaman itu, Indonesia juga memiliki komoditas perdagangan lain yaitu rempah-rempah. Perdagangan rempahrempah yang berpusat di Maluku ini mendapat perhatian para raja di Pulau Jawa termasuk salah satunya adalah Kerajaan Majapahit. Untuk mendapatkan rempah-rempah Maluku maka para raja biasanya mengirimkan konvoi dagang ke Maluku yang dipimpin langsung oleh para pangeran. Oleh karena kondisi politis yang tidak menentu dalam lingkungan Kerajaan Majapahit, maka beberapa pangeran cenderung memilih tinggal menetap di kawasan timur nusantara ternasuk pulau Solor. Pada akhirnya mereka tidak hanya mengincar rempah-rempah yang ada di Maluku, tetapi juga kayu cendana yang ada di Solor. 
WAKHYUNING NGARSIH

\section{Perebutan Kekuasaan di Solor}

Dalam perjalanan sejarahnya, Solor yang kecil selalu menjadi incaran dan sasaran dari para pengusa luar. Perebutan pengaruh kuasa atas pulau Solor menyebabkan pulau Solor selalu berganti tuan dari waktu ke waktu. Sebut saja Kerajaan Majapahit, Ternate, Portugis dan Belanda. Selain itu, Solor juga diwarnai permusuhan keras antara Paji dan Demong. Berikut akan diuraikan secara lebih mendalam mengenai kekuasaan kerajaan maupun bangsa luar beserta pengaruhnya di Solor.

\section{Kerajaan Majapahit}

Kerajaan Majapahit atau sering disebut dengan Wimatikta merupakan kerajaan terbesar di nusantara. Kerajaan ini dapat dikatakan sebagai kerajaan pada masa hindu budha yang paling lama bertahan dan paling luas wilayahnya (Haryono, 1997, hlm. 107). Tidak hanya di Pulau Jawa saja, Majapahit bahkan seringkali melakukan perluasan wilayah hingga luar Jawa.

Perluasan wilayah dan pengaruh Majapahit ini semakin memperluas lingkaran-lingkaran wilayah dalam tatanan Majapahit. Ada wilayah ibukota dan sekitarnya, wilayah tradisional atau bagian utama dari kemaharjaan dan wilayah-wilayah baru yang menjadi koloni baik langsung maupun tidak. Kolonikoloni tersebut ada yang secara langsung diperintah oleh keluarga raja, utusanutusan Majapahit ataupun penguasapenguasa lokal namun tetap dalam pantuan Majapahit. Pengembangan identitaspun ternyata tetap meninggalkan ciri khas Majapahit sebagai kerajaan utama (Munandar dalam Wahyudi, 2013, hlm. 91).
Salah satu hasil perluasan wilayah Majapahit di luar pulau Jawa adalah Solor. Proses pemusatan kekuasaan Majapahit di pulau Solor dipersiapkan melalui kegiatan politik dan kegiatan ekonomi khususnya dalam bidang perdagangan. Kontak antara Majapahit dan Solor telah diberitakan dalam syair ke XIV Negarakertagama yang menyebutkan bahwa Solor merupakan wilayah Majapahit yang keenam.

Dalam rangka perluasan wilayah dan kekuasaan ke bagian Timur khususnya Nusa Nipa dan sekitarnya, Majapahit menjadikan Solor sebagai basis. Pemilihan Solor sebagai basis didasarkan pada pertimbangan keamanan dan strategi. Pulau Solor dianggap sebagai tempat yang aman dan strategis untuk melaksanakan penaklukan terhadap Nusa Nipa. Penaklukan terhadap Nusa Nipa mulai dilakukan oleh Majapahit sekitar tahun 1357. Proses penaklukan tersebut, Majapahit banyak dibantu oleh para pemberani yang terdiri dari orang-orang Solor dan orang-orang Sikka. Menurut catatan para pedagang Portugis, kekuasaan Majapahit di Solor bertahan hingga tahun 1522. Meski kekuasaan Majapahit berakhir, namun pengaruhnya begitu dirasakan.

Perluasan wilayah di Solor mengakibatkan pengaruh Jawa Majapahit sangat dirasakan dalam tatanan kehidupan orang Solor. Muncul istilah-istilah yang merepresentasikan keberadaan orang Jawa Majapahit di Solor. Seperti misalnya sebutan Jawa Nuhan. Sebutan Jawa Nuhan sangat memperjelas keberadaan orang Jawa di pulau Solor sebelum berpindah ke Larantuka yang terletak di Nusa Nipa. Nuhan dalam bahasa Lamaholot berarti pulau. Jawa Nuhan berarti orang Jawa yang berdiam di pulau. Pulau yang dimaksudkan disini adalag pulau Solor. 
Ada lagi sebutan untuk Lio Kowe Jawa yang digunakan untuk menyebut orangorang Krowe Sikka dan orang-orang Lamaholot. Sebutan ini lazim digunakan untuk menjelaskan berbagai unsur Jawa yang ada di Krowe yakni orang-orang Jawa yang tinggal di Sikka dan Flores Timur.

Selain istilah, pengaruh Jawa Majapahit juga dapat dilihat dari segi asal usul suku yang beragam. Penduduk yang tinggal di sekitar Pegunungan Lewolein misalnya memiliki hubungan erat dengan suku Melayu dan Jawa. Hal ini tampak dari syair-syair yang sering dibawakan yang berkaitan erat dengan sejarah suku seperti "Sina Jawa Malaka Keling Surabaya". Tidak hanya itu, secara fisik penduduk yang tinggal wilayah ini memiliki bentuk yang hampir sama dengan penduduk pulau Jawa pada umunya. Seperti misalnya memiliki badan yang tidak terlalu besar, tubuh langsing, air muka yang halus, rambut hitam ikal, batang hidung yang pipih, warna kulit sawomatang, lengan dan jari yang halus, perut yang tidak gendut serta gerak-gerik yang serba anggun.

\section{Kerajaan Ternate}

Sejak runtuhnya kekuasaan Kerajaan Majapahit, Solor dan pulau-pulau di sekitarnya menjadi rebutan kerajaankerajaan besar pada masa itu termasuk Ternate. Kapan tepatnya Kesultanan Ternate mulai berpengaruh di Solor tidak diketahui secara pasti. Meski demikian, diperkirakan kehadiran pengaruh Ternate di kawasan Pulau Solor berkisar antara akahir pemerintahan Majapahit dan awal kedatangan Portugis.

Tanda-tanda kehadiran dan pengaruh dan kekuasan Ternate di Solor tampak jelas dalam masa pemerintahan Sultan Baabullah. Pengaruh kekuasaan Ternate di Solor baru berakhir sekitar tahun 1683. Hal ini tampak tersirat dalam perjanjian antara pihak Belanda dan Sultan Ternate. Dalam naskah perjanjian tersebut tersimpul bahwa selama masa pemerintahan Portugis di Solor, kepualaun Solor sebenarnya secara formal masuk dalam wilayah kekuasaan Sultan Ternate.

Kehadiran Portugis dan usahanya untuk meletakkan dasar kekuatannya di Ternate selalu mendapat perlawanan sengit dari pihak Ternate. Perlawanan pihak Ternate dibangun atas dasar keyakinan bahwa Portugis tidak memiliki hak atas Ternate dan semua wilayah yang bernaung dibawah kekuasaan Ternate termasuk kepulauan Solor. Dalam keyakinan dasar ini, pihak Ternate tetap mengakui Solor sebagai wilayah jajahannya meski secara de facto kepulauan Solor dikuasai oleh pihak Portugis. Oleh karena itu melalui perjanjian tahun 1683 antara Belanda dan Sultan Ternate ditegaskan bahwa kepulauan Solor dibebaskan dari kekuasaan Sultan Ternate dan dimasukkan dalam wilayah kekuasaan Belanda.

Secara sosio-kultural, pengaruh kesultanan Ternate di Solor pada umumnya masih bertahan hingga saat ini. Jejak pengaruh kultural ini masih tampak dalam beberapa hal seperti ide ketuhanan dan bahasa. Dalam hal ide ketuhanan, nama untuk wujud tertinggi yang digunakan oleh suku-suku di kepulauan Solor dan Krowe Sikka memiliki kemiripian dengan nama untuk wujud tertinggi yang digunakan oleh suku-suku di kawasan kepualaun Ambon. Orang Lamaholot menyebut wujud tertinggi dengan sebutan "Lera Wulan Tana Ekan", sedangkan orang Krowe Sikka menyebutnya dengan "Lero Wulan Nian Tana”. Sementara itu, suku-suku di 
kepulauan Ambon menyebutnya dengan "Duad Lera Wulan". Selain ungkapan wujud tertinggi, baik orang Ternate maupun orang Lamaholot memperlihatkan kesamaan dalam penyembahan terhadap binatang tertentu yang dianggap keramat, seperti penyembahan terhadap ibunda naga.

Tidak hanya itu saja, kesamaan juga dapat dilihat secara sosio-linguistik. Terdapat banyak kesamaan antara ungkapan-ungkapan bahasa Lamaholot dengan ungkapan-ungkapan bahasa dari suku-suku penghuni kepulauan Ambon. Lantaran pengaruh sosio-linguistik begitu kuat dari Maluku dan Jawa atas kepualauan Solor, maka kedua wilayah di bagian timur dari Nusa Nipa ini lazim disebut "Sika Maluku Jawa Malaka, atau dalam ungkapan lengkap sering disebut "Sika Maluku Kuwung Jawa Malaka Kajang”. Ungkapan ini selain memperlihatkan pengaruh bahasa juga mengungkapkan kiblat politik dari kedua wilayah ini yakni Jawa dan Maluku. Sementara itu, secara demografis dikatakan bahwa pengaruh etnis Maluku di kawasan Krowe Sikka dan Lamaholot jauh lebih kuat dibandingkan pengaruh Jawa, Malaka dan Melayu. Hal ini tampak jelas dalam penampilan fisik orang Lamaholot yang memperlihatkan kemiripan dengan tampilan fisik orang Ternate.

Meski secara kultural pengaruh Ternate cukup kuat di kawasan Solor, namun hal ini bukanlah yang utama. Orientasi utama dari Kesultanan Ternate meluaskan pengaruh dan kekuasaannya ke kawasan ini lebih terdorong oleh pertimbangan politis dan ekonomis. Solor dan kepulauan sekitarnya sejak zaman Majapahit telah dijadikan sebagai tempat penimbunan kayu cendana.
Ketika Majapahit mengalami kemunduran, pusat perdagangan sekaligus tempat penimbunan kayu cendana dipindahkan ke Ternate. Kehadiran unsur-unsur kultur Ternate di kepulauan Solor dan sekitarnya terjadi sebagai akibat sampingan dari kehadiran pengaruh dan kekuasaan politis dan ekonomis Ternate di kawasan ini.

\section{Portugis}

Pada awal abad ke XVI Portugis membuat ekspedisi ke Ternate dan Tidore. Dalam perjalanan ekspedisi ini Portugis berkenalan dengan Solor dan Krowe Sikka. Searah dengankebijakan Majapahit, bangsa Portugis lalu menjadikan Solor dan Krowe Sikka sebagai benteng pertahanannya. Sebagaimana Majapahit, bangsa Portugis juga merasa sangat tertarik dengan pulau Solor. Tidak ada alasan lain yang lebih mendasar selain alasan perdagangan dan alasan ekonomis. Solor sangat dikenal sebagai tempat penimbunan kayu cendana. Ketertarikan Portugis terhadap pulau Solor dibuktikan oleh kesediaan seorang saudagar Portugis untuk menetap bahkan meninggal di Pulau Solor. Dia adalah Juan Suares, saudagar yang pernah membaptis Raja Solor. Pembaptisan ini menjadi awal mula dari karya misionaris di Solor.

Karya misionaris Portugis di Solor inilah yang kemudian berpengaruh secara kultural bagi masyarakat khususnya dalam bidang penyebaran agama Katolik. Menurut catatan B.J.J. Visser (Lein, 1995, hlm. 40), misi penyebaran agama di Solor tidak hanya terbatas di pulau Solor sendiri, tetapi mencakup juga kawasan sekitar Larantuka yakni wilayah-wilayah yang berjarak sekitar 30 mil dari Larantuka termasuk Tonggo, Sikka, Paga dan Ende.

Kehadiran misi Portugis di Pulau Solor menyebabkan karya misi di kawasan 
ini selalu disebut dengan misi Solor. Dalam perkembangan selanjutnya, misi Solor diganti namanya menjadi misi Flores karena pusat misi dipindahkan ke Larantuka. Awal mula misi Solor berangkat dari kebiasaan orang Portugis untuk mengadakan perjalanan dagang ke kawasan timur dan Malaka. Bersamaan dengan perjalanan dagang, mereka serentak melaksanakan tugas missioner yakni mengajar agama dan melaksanakan pembaptisan.

Upaya kristenisasi di Solor sebelum ditangani oleh para imam, sebenarnya telah dirintis oleh kaum awam Portugis. Dikisahkan pada tahun 1556 Pater Antonio de Taveira membaptis sekitar 5000 orang di daratan Timor. Sementara itu pembaptisan juga terus bertambah di pulau Solor dan pulau Ende. Rintisan misionaris Solor yang dilakukan oleh Pater Antonio de Taveira kemudian mendapat perhatian dari Uskup Jorghe de Santa yang berkedudukan di Malaka. Pada tahun 1561, Uskup Malaka tersebut kemudian mengirim tiga orang misionaris ke Solor untuk memulai karya misi secara tetap. Para misionaris itu adalah Pater Antonio de Crus, Pater Simao de Chagas dan Bruder Alexio. Hubungan para misionaris dengan penduduk setempat sangat baik. Banyak penduduk setempat membiarkan diri mereka dibaptis menjadi Katolik.

Untuk meletakkan dasar misi yang kuat, para misionaris ini memulai usaha mereka dengan membangun rumah dan gerejayang diberikan pagaryang kuatuntuk mencegah serbuan dari para bajak laut yang berasal dari Jawa, Goa dan Makassar. Dalam proses pembangunan para paderi banyak mendapat bantuan dari penduduk pribumi. Merekajuga membangun benteng dengan menggunakan bahan-bahan lokal yang sederhana yakni batang pohon lontas. Sedangkan bagian luar ditanam pohon perang dan kaktus. Tindakan ini dinilai sangat bijaksana karena zaman itu banyak bajak laut melaksanakan penyerangan terhadap pusat misi Solor.

Meski sudah dibangun benteng sebagai media pertahanan, tidak berarti Portugis aman dari serangan kelompok lain. Selain bajak laut, Portugis juga seringkali mendapat serangan dari kelompok islam yang tidak sepakat adanya misionaris Portugis di Solor. Tidak hanya kelompok islam, Portugis juga mendapat serangan dari Belanda. Serangan dari berbagai pihak inilah yang kemudian menggagalkan pertahanan dan misonaris Portugis di Solor. Secara garis besar, kegagalan Portugis menguasai Solor baik dalam bidang agama, politik maupun ekonomi dapat digambarkan sebagai berikut:

a. Pusat pertahanan Portugis di Asia pada umumnya dan Nusantara pada khususnya letaknya saling berjauhan. Pusat Portugis di Asia seperti India, Sailan dan Malaka letaknya saling berjauhan. Hal ini sangat mempersulit koordinasi dan konsolidasi. Sementara di kawasan nusantara basis kekuatan Portugis di terdapat di pulau Jawa, Maluku Makasar, Timor, Ende dan Solor. Apalagi pulau Ende dan Solor sebagai inti pertahanan Portugis tidak didukung oleh kekuatan tenaga yang memadai. Penduduk Ende dan Solor sangat kecil sehingga tidak memberikan dukungan yang memadai terhadap Portugis.

b. Pulau Flores sebagi basis kekuatan yang baru tidak dikelola secara memadai. Kekurangan tenaga dapat menjadi satu sebab kegagalan Portugis 
untuk mempertahankan pengaruh dan kekuasaan di kawasan kepulauan Solor ini.

c. Adanya perlawanan gigih yang dilancarkan oleh pihak Paji terhadap Demong. Portugis sebagai pengembang agama Katolik di kawasan ini memberikan dukungan kepada Demong yang adalah penganut agama Katolik. Dengan demikian dukungan Portugis terhadap Demong menyeret pihak Portugis serentak menjadi musuh Paji yang notabene didukung oleh kekuatan Islam.

d. Orang Portugis di Solor dinilai oleh orang Islam Lamakera dan Lohayong sebagai biang keladi dari segala bencana dan malapetaka yang terjadi di kawasan ini karena mereka bertindak keras terhadap orang-orang Paji.

e. Semua unsur Islam yang tergabung dalam kesatuan bajak laut Jawa, Goa, Makassar, Ternate dan Bima mengambil sikap membenci Portugis karena mereka mengembangkan sistem monopoli dalam bidang perdagangan rempah-rempah dan kayu cendana.

f) Dalam konteks persaingan semacam ini pihak Belanda pandai memanfaatkan situasi. Pihak Belanda memprovokasi pihak yang berseberangan dengan Portugis dan membakar api kebencian yang sangat hebat terhadap Portugis sehingga dalam posisi persaingan ini pihak Portugis menjadi sangan terpojok.

Banyaknya pihak yang menjadi musuh Portugis, menjadikan posisi serta kedudukan Portugis di Solor semakin terdesak. Pada tahun 1646 secara definitif Portugis meninggalkan Solor dan mulai menetap di Larantuka sambil diawasi secara tetap oleh pihak Belanda dari benteng Solor.

\section{Belanda}

Usai Portugis, Solor sempat jatuh ke tangan Belanda. Perebutan kekuasaan atas Solor sempat terjadi antara kedua belah pihak ini. Belanda dirasa sebagai musuh berat oleh Portugis. Selain ada permusuhan di bidang ekonomi dan politik antara keduanya, ada juga permusuhan religius karena kedua bangsa ini memiliki iman dan keyakinan yang berbeda. Bangsa Portugis adalah penganut agama Katolik sedangkan bangsa Belanda adalah penganut agama Protestan Calvinis. Persaingan dan pertentangan begitu hebat antara keduanya menyebabkan bangsa Portugis menghentikan segala jenis kegiatannya termasuk kegiatan penyebaran agama Katolik di kawasan ini.

Secara resmi kekuasaan Belanda di Solor ditandai dengan kemenangannya atas Portugis pada tahun 1613 dan 1618. Kemenangan tersebut mengakibatkan berakhirnya kekuatan Portugis dalam bidang politik, ekonomi dan agama di Solor. Meski sempat berkuasa di Solor, Belanda tidak memiliki pengaruh signifikan di kawasan ini karena perhatian mereka terfokus pada pengembangan wilayah lain.

\section{Permusuhan antara Paji dan Demong}

Suku yang mendiami Solor adalah suku Lamaholot. Suku Lamaholot ini umumnya dibagi atas dua kelompok besar yakni Orang Paji dan Orang Demong. Orang Paji umumnya mendiami wilayah timur Solor yakni Lamakera, Lohayong dan beberapa kampung kecil di sekitarnya. Sedangkan Orang Demong mendiama wilayah barat khususnya pada kampung Pamakayo dan 
Lewolein serta beberapa kampung kecil lainnya.

Antara Orang Paji dan Demong selalu terjadi permusuhan. Unsur lain yang mempertajam permusuhan ini adalah bahwa orang Paji diperintah oleh Adonara yang umumnya beragama Islam, sedangkan orang demong diperintah oleh raja-raja Katolik yang dilindungi oleh Portugis. Keberadaan Portugis sebagai pelindung sekaligus memiliki dampak keagamaan.

Pernusuhan antara Paji dan Demong adalah permusuhan klasik dengan alasan dan latar belakang religius. Paji umumnya beragama islam sedangkan Demong umumnya beragama Katolik. Ketika Portugis menyatakan keberpihakannya kepada Orang Demong, hal ini ditafsirkan oleh kelompok Paji sebagai suatu upaya untuk memberantas keberadaan Orang Paji. Maka terjadilah usaha dan perjuangan kedua belah pihak untuk saling menguasai dengan berbagai cara. Karena keberpihakan Portugis ditujukan kepada Orang Demong maka setiap ada gejolak politik sekaku ditafsirkan sebagai ulah Portugis yang beragama Katolik dan didukung oleh para padri Katolik. Permusuhan antara kedua belah pihak inilah yang pada akhirnya juga turut andil dalam mengakhiri masa kekuasaan Portugis di wilayah Solor.

Dalam perjalanan sejarahanya, meski banyak pihak yang memperebutkan Solor, namun pulau Solor tetap mempertahankan karakteristik sistem pemerintahan adat yang ditandai dengan kehadiran kepemimpinan catur tunggal. Catur tunggal dalam konteks kehidupan masyarakat Solor terdiri dari pimpinan empat suku yang lazim disebut dengan Koten, Kelen, Hurit dan Maran.
Kepemimpinan yang bercorak catur tunggal ini sangat mewarnai kepemimpinan pada tingkat kerajaan hingga tingkat desa. Dalam tingkat kerajaan, kekuasaan tertinggi berada dalam tangan seorang raja. Dia melaksanakan fungsi Koten, baik dalam urusan pemerintahan maupun dalam urusan keagamaan. Dalam sistem pemerintahan catur tunggal, raja bukanlah satu-satunya pemegang kekuasaan tertinggi. Raja selalu dibantu oleh tiga unsur yang lain yakni Kelen, Hurit dan Maran. Kelen adalah pembantu raja yang ditugaskan untuk mengurusi hubungan antar kerajaan. Diantaranya yaitu menentukan kerajaan itu bisa berada dalam masa damai atau perang serta melaksanakan tugas-tugas diplomatis untuk menjembatani relasi antar kerajaan. Maran adalah pembantu raja yang melaksanakan tugas sebagai juru bicara baik dalam bidang politis-profan maupun dalam bidang religius. Sedangkan Hurit merupakan pembantu raja yang melaksanakan ugas-tugas pengamanan dan ketertiban atas kerajaan.

Meski masing-masing melaksanakan tugas khusus, namun mereka tetap merupakan satu kesatuan dalam urusan pemerintahan dan keagamaan demi kebaikan dan kesejahteraan rakyat banyak. Dalam melaksanakan tugas, catur tunggal selalu diutamakan prinsip musyawarah untuk mufakat. Setiap kebijakan dilaksanakan demi kepentingan orang banyak selalu ditempuh melalui jalan musyawarah.

\section{SIMPULAN}

Solor sebagai primadona perdagangan cendana pada masa itu menyebabkan wilayahnya menjadi incaran kekuasaan oleh banyak pihak. Sebut saja Majapahit, 
Ternate, Belanda dan Portugis. Selain berhasrat menguasai Solor, mereka juga memperluas pengaruhnya dalam hal politik, ekonomi bahkan agama. Sehingga tidak mengherankan apabila jejak-jejak peninggalan kekuasaan mereka masih tergambar jelas melalui pengaruhnya terhadap kehidupan masyarakat Solor itu sendiri.

Pengaruh tersebut pada akhirnya menyebabkan pada munculnya masyarakat Solor yang multikultur. Multikulturalisme masyarakat Solor sendiri tercermin melalui berbagai hal, diantaranya dari keragaman etnis, agama dan bahasa. Keragaman etnis tampak dari masyarakat yang menghuni pulau Solor itu sendiri. Banyaknya para pendatang yang pada mulanya hanya singgah kemudian memutuskan untuk menetap, menyebabkan semakin banyak pula keragaman etnis di kawasan ini. Agama yang dianut oleh masyarakat pun menjadi beragam, seperti Islam dan Katolik. Secara sosio linguistik, banyak muncul ungkapan maupun syair-syair yang memiliki hubungan erat dengan suku lain yang pernah singgah di Solor.

Sempat diwarnai konflik karena keragaman tersebut, khusunya dalam bidang agama, namun pada akhirnya hal ini hanya menjadi sebuah pengalaman masa silam. Kehidupan dewasa ini, dikotomi atas nama agama dan politik telah hilang. Sebagai gantinya, muncul persatuan dan persaudaraan yang tinggi antara suku-suku penghuni Pulau Solor karena memiliki sejarah asal-usul suku yang sama. Meski secara formal agama yang dianut kini adalah agama Islam dan Katolik, namun mereka memiliki latar belakang agama dan kepercayaan asli yang sama yaitu mengakui adanya unsur wujud tertinggi yang lazim dikenal dengan sebutan "Bapa Kelake Lera Wulan Ina Kewae Tana Ekan”.

Bercermin pada pengalaman masa lampau yang terjadi di pulau Solor, baik pengalaman positif maupun pengalaman negatif, diharapkan masyarakat Solor pada umumnya dan masyarakat Lamaholot pada khususnya dapat mengambil bagian dalam memberi isi dan mutu pembangunan guna mewujudkan kesatuan Negara Republik Indonesia dalam membangun masyarakat yang adil dan makmur berdasarkan Pancasila dan Undang-Undang Dasar Negara Republik Indonesia Tahun 1945.

Alat musik Angklung Gubrag sudah digunakan sejak lama oleh masyarakat Cigudeg sebagai media ritual dalam upacara Seren Taun yang bertujuan untuk memuja Nyi Pohaci. Penggunaannya

\section{DAFTAR PUSTAKA}

Barker, C. (2004). Cultural Studies, Teori dan Praktek. Yogyakarta: Kreasi Wacana.

Burke, P. (2001). Sejarah Dan Teori Sosial. Jakarta: Yayasan Obor Indonesia.

Daliman, A. (2012). Metode Penelitian Sejarah. Yogyakarta: Penerbit Ombak. Gottschalk, L. (1986). Mengerti Sejarah. Ter. Nugroho Notosusanto. Jakarta: Universitas Indonesia Press.

Haryono, T. (1997). Kerajaan Majapahit: Masa Sri Rajasanagara Sampai Girindrawarddhana. Jurnal Humaniora No.5.

Lein, G.S., \& Toron, Y.M. (Eds). (1995). Sejarah Solor: Melacak Jejak Majapahit dan Portugis.

Mudzhar, M.A. (2004). Kebijakan Negara dan Pemberdayaan Lembaga dan Pemimpin agama dalam rangka 
keharmonisan hubungan antar umat beragama dalam Damai di Dunia Damai untuk Semua: Perspektif Berbagai Agama. Jakarta: Proyek Peningkatan Pengkajian Kerukunan Hidup Umat Beragama, Puslitbang Kehidupan Beragama, Badan Litbang Agama dan Diklat Keagamaan, Depag RI.

Tinambunan,H.S.R.(2016).Pemberdayaan Masyarakat Desa Pesisir Melalui Penguatan Budaya Maritim Dalam
Menghadapi Pasar Bebas Masyarakat Ekonomi Asean. Fiat Justisia Journal of Law, 10(1) Januari-Maret.

Wahyudi, Deny Yudo. 2013. Kerajaan Majapahit: Dinamika Dalam Sejarah Nusantara. Jurnal Sejarah dan Budaya, 7 (1) Juni.

United Nations Convention on the Law of the Sea (1982). 